\title{
DESAIN MESIN PENCACAH SAMPAH ORGANIK RUMAH TANGGA UNTUK PEMBUATAN PUPUK KOMPOS
}

\author{
Evi Sunarti Antu ${ }^{1)}$, Yunita Djamalu ${ }^{2)}$ \\ 1) Tim Pengajar pada Program Studi Mesin dan Peralatan Pertanian, Politeknik Gorontalo \\ ${ }^{2)}$ Tim Pengajar pada Program Studi Mesin dan Peralatan Pertanian, Politeknik Gorontalo
}

\begin{abstract}
ABSTRAK
Permasalahan sampah di Indonesia masih belum tertangani dengan baik. Padahal sampah merupakan sumber penyakit, pencemaran lingkungan dan sumber masalah lainnya. Pada penelitian ini akan dirancang sebuah alat pengomposan dala skala rumah tangga sehingga sampah organik untuk setiap rumah tangga dapat langsung diolah dan digunakan. Desain mesin pengomposan dirancang dengan menyesuaikan tinggi badan masayarakat pada umumnya dengan memperhatikan keamanan dan kenayaman pengguna. Bahan yang digunakan pada silinder pencacahan dengan laci penyimpanan kompos berupa stainless still agar tidak terjadai korosi atau berkarat akibat penggunaan bahan sampah yang basah. Penggerak mesin menggunakan dinamo untuk mempemudah pemakaian. Mesin pengomposan terdapat 4 buah rak/laci. Setiap rak/laci mempunyai volume $0,032 \mathrm{~m}^{3}$. Rata-rata waktu pencacahan sampah organik dengan berat 1200 gram yakni 48 detik. Sehingga mesin ini mampu mencacah sampah organik dengan kapasitas $25 \mathrm{gr} / \mathrm{detik}$.
\end{abstract}

Kata kunci : Alat pengomposan, pupuk kompos, sampah, organik

\section{DESIGN AND PERFORMANCE TEST TOOLS FOR HOUSEHOLD ORGANIC WASTE}

\begin{abstract}
The problem of waste in Indonesia has not been handled properly. Though garbage is a source of disease, environmental pollution and other sources of problems. In this study, a composting tool will be designed in the household scale so that organic waste for each household can be directly processed and used. The design of the composting machine is designed by adjusting the height of the community in general by paying attention to the security and comfort of the user. The material used in the enumeration cylinder with a compost storage drawer, in the form of stainless still so as not to cause corrosion or rust. Due to the use of wet waste material. The engine drives uses a dynamo to facilitate use. Composting machine has four shelves drawers. Each shelf/drawer has a volume of $0.032 \mathrm{m3}$. The average time for enumerating organic waste with a weight of 1200 grams is 48 seconds. So that this machine is able to cut organic waste with a capacity of $25 \mathrm{gr} / \mathrm{sec}$.
\end{abstract}

Keywords: Composting equipment, compost, garbage, organic 


\section{PENDAHULUAN}

Permasalahan sampah di Indonesia masih belum tertangani dengan baik. Padahal sampah merupakan sumber penyakit, pencemaran lingkungan dan sumber masalah lainnya.Dari data BPS, 2016Kota Gorontalo adalah wilayah yang geografisnya terletak di antara 00.28'.17" - 00 35'.56" Lintang Utara dan 122.59'.44" Bujur Timur. Kota Gorontalo merupakan salah satu kota yang ada di Provinsi Gorontalo.

Sembilan kecamatan di Kota Gorontalo ini terbagi menjadi 50 Kelurahan di mana semua kelurahan sudah termasuk ke dalam kategori kelurahan swakarya. Kota Gorontalao mempunyai 194 lingkungan, 280 RW dan 984 RT. Luas keseluruhan wilayah Kota Gorontalo adalah $79.03 \mathrm{~km}^{2}$ dan terbagi ke dalam 9 kecamatan dan 50 kelurahan diantaranya kelurahan Moodu dengan jumlah penduduk yang dibagi atas 3.927 jumlah jiwa dan 1.078 jumlah KK dan 769 rumah sebagai hunian masyarakat sehingga diperkirakan ada sekitar 769 rumah yang menghasilkan sampah baik sampah organic maupun sampah non organic untuk diangkut oleh petugas pengumpul sampah untuk kemudian dikumpulkan ke TPS (Tempat Penampungan Sampah) yang ada di kelurahan Moodu.

Dari data TPS KSM di ketahui sampah rumah tangga di Gorontalo capai 200 ton per hari namun dari volume sampah Kota Gorontalo, jumlah armada tidak sesuai sehingga menyulitkan Dinas Lingkungan Hidup (DLH) Kota Gorontalo dalam pengangkutan sampah setiap hari."Tiap armada dapat mengangkut empat sampai lima ton per hari, sedangkan jumlah armada seKota Gorontalo hanya 22unit. Sementara itu, Bank Sampah Mutiara (BSM) di Kelurahan Moodu, Kecamatan Kota Timur, mampu menyerap sampah sebanyak $60 \mathrm{~kg}$ setiap hari di kelurahan Moodu Kota Gorontalo.Sampah yang terkumpul kemudian dipilah dan dikemas oleh empat pekerja KSM, dan dijual ke perusahaan swasta yang akan mengirimkannya ke Surabaya dan Malang untuk didaur ulang namun ada banyak sampah yang tidak bisa dikirim dan dijadikan pupuk kompos yang dimanfaatkan dan didistribusikan kepada masyarakat sebagai alternatif untuk pengolahan lahan pertanian ataupun perkebunan masyarakat.
Beberapa kendala yang ada di TPS Moodu dalam hal pengomposan sampah adalah masih menggunakan cara manual sehingga pupuk kompos yang dihasilkan masih relative sedikit dan tidak memenuhi permintaan ataupun kebutuhan masyarakat khususnya yang ada di kelurahan Moodu. Pertimbangan desain awal dibuat dengan tong biru bekas sebagai tempat bioreactor pengomposan yang dilubangi dibawahnya dan ditambahkan lempengan alumunium sebagai alasnya yang berfungsi menampung kompos dan kemudian masih diaduk secara manual. Jadi dari desain yang ada dikembangkan dengan kapasitas tampung hasil kompos lebih besar dan setiap raknya bisa di tukar dan tabung penampung dibuat dari alumunium dan menggunakan dynamo untuk menggerakan pisau pengaduk sampah untuk pengomposan. Desain ini lebih ditekankan pada tingkat kepraktisan sistem pencacahan sampah organik, sistem pengadukan otomatis dan wadah hasil pengomposan dengan 3 laci. Harga produk harus terjangkau karena ditujukan untuk user dengan perekonomian menengah kebawah di Kota Gorontalo khususnya Desa Moodu dan TPS yang ada diseluruh Kota Gorontalo. Produk disiapkan agar dapat dibuat sendiri (DIY/ Do It Yourself) secara mandiri oleh masyarakat Desa Moodu. Hasil produk akhir diharapkan dapat digunakan secara massal di kalangan masyarakatk hususnya di Kota Gorontalo sehingga dapat menjadi solusi efektif untuk menyelesaikan permasalahan sampah organik skala rumah tangga dan membantu TPS yang ada diseluruh Kota Gorontalo.

\section{Justifikasi Permasalahan}

Kelurahan Moodu, Kecamatan Kota Timur, mampu menyerap sampah sebanyak $60 \mathrm{~kg}$ setiap hari. Sampah tersebut terdiri dari sampah organik dan sampah non organik dimana sampah-sampah tersebut diolah dengan cara dicacah ulang dan dipres namun dalam pengelolaannya proses pengepresan masih membutuhkan waktu yang lama karena sampah organik dan non organik belum terpisah otomatis dan belum menghasilkan pupuk kompos untuk memupuk padi sawah di lahan depan TPS yakni sawah milik pemerintah dan juga belum didistribusikan ataupun dimanfaatkan untuk lahan sawah masyarakat. 
Permasalahan prioritas

Politeknik Gorontalo dalam hal ini akan melakukan pembenahan dan penambahan alat pengolahan sampah untuk pengomposan sebagai upaya peningkatan produksi pupuk organik bagi usaha tani padi sawah dimana mengenai masalah prioritas adalah sebagai berikut :

1. Masalah alat pencacah sampah organic dan non organic yakni alat pencacah sampah yang rusak sehingga hasil daur ulang belum maksimal dan belum menghasilkan pupuk organik.

2. Belum menghasilkan pupuk kompos yang dapat dimanfaatkan dan didistribusikan kepada masyarakat sebagai alternatif untuk pengolahan lahan pertanian ataupun perkebunan masyarakat.

3. peralatan pengolahan sampah yang belum dipergunakan dengan maksimal dan belum dilengkapi dengan system instalasi pengolah sampah yang baik sehingga proses pengelolaan sampah belum efektif.

Tujuan Penelitian

Dari permasalahan yang ada, solusi persoalan yang ditawarkanyang menjadi tujuan dalan penelitian ini adalah:

1. Pembuatan alat pengompos sampah organic otomatis

2. Menganalisis uji kinerja alat pengompos sampah organik

3. Menghitung lama waktu yang dibutuhkan untuk membuat pupuk kompos dari sampah organik rumah tangga.

\section{TINJAUAN PUSTAKA}

\section{Analisis Situasi}

Gambaran Umum Wilayah Kota Gorontalo menjelaskan Kondisi Umum Kota Gorontalo yang mencakup : Kondisi Fisik, Kependudukan, Administratif, Keuangan dan Perekonomian Daerah, Penataan Ruang, Struktur Organisasi serta tugas dan tanggung jawab perangkat daerah.

Dari data BPS, 2016Kota Gorontalo adalah wilayah yang geografisnya terletak di antara 00.28'.17" - 00 35'.56" Lintang Utara dan 122.59'.44" Bujur Timur. Kota Gorontalo merupakan salah satu kota yang ada di Provinsi Gorontalo. Berdasarkan letak geografis, batas administratif kota Gorontalo sebelah utara berbatas dengan Kecamatan
Tapa, Kabupaten Bonebolango, Sebelah Timur dengan Kecamatan Kabila dan Kecamatan Tilongkabila, Kabupaten Bonebolango, sebelah Barat dengan Kecamatan Telaga, Batudaa, dan Batudaa pantai Kabupaten Gorontalo sedangkan sebelah Selatan dengan Teluk Tomini.

Setelah melalui beberapa kali proses pemekaran kecamatan dan kelurahan, saat ini Kota Gorontalo terdiri atas 9 (sembilan) kecamatan dan 50 kelurahan dengan luasan masing-masing kecamatan yaitu :

- Kecamatan Kota Barat dengan wilayah seluas $20,08 \mathrm{~km}^{2}$ atau $23,40 \%$

- Kecamatan Dungingi dengan luas wilayah sebesar $4,67 \mathrm{~km}^{2}$ atau $6,33 \%$

- Kecamatan Kota Selatan dengan luas wilayah sebesar 2,81 $\mathrm{km}^{2}$ atau 3,55\%

- Kecamatan Kota Timur dengan luas wilayah sebesar 5,32 $\mathrm{km}^{2}$ atau $6,73 \%$

- Kecamatan Kota Utara dengan luas wilayah sebsar 8,02 $\mathrm{km}^{2}$ atau 10,15\%

- Kecamatan Kota Tengah, dengan luas wilayah sebesar $4,81 \mathrm{~km}^{2}$ atau $6,08 \%$

- Kecamatan Hulonthalangi dengan luas Wilayah sebesar $14,23 \mathrm{~km}^{2}$ atau $18,01 \%$

- Kecamatan Dumbo Raya, dengan luas Wilayah sebesar $14,03 \mathrm{~km}^{2}$ atau $17,75 \%$

- Kecamatan Sipatana dengan luas wilayah $: 5,05 \mathrm{~km}^{2}$ atau $6.39 \%$

Sembilan kecamatan di Kota Gorontalo ini terbagi menjadi 50 Kelurahan di mana semua kelurahan sudah termasuk ke dalam kategori kelurahan swakarya. Kota Gorontalao mempunyai 194 lingkungan, 280 RW dan 984 RT. Luas keseluruhan wilayah Kota Gorontalo adalah $79.03 \mathrm{~km}^{2}$ dan terbagi ke dalam 9 kecamatan dan 50 kelurahan diantaranya kelurahan Moodu dengan jumlah penduduk yang dibagi atas 3.927 jumlah jiwa dan 1.078 jumlah KK dan 769 rumah sebagai hunian masyarakat sehingga diperkirakan ada sekitar 769 rumah yang menghasilkan sampah baik sampah organic maupun sampah non organic untuk diangkut oleh petugas pengumpul sampah untuk kemudian dikumpulkan ke TPS (Tempat Penampungan Sampah) yang ada di kelurahan Moodu.

\section{Keadaan Tanah dan Geologi}

Tanah diartikan adalah lapisan atas bumi yang merupakan campuran dari pelapukan batuan dan jasad makhluk hidup yang telah mati dan 
membusuk. Oleh pengaruh cuaca, jasad makhluk hidup tadi menjadi lapuk, mineralmineralnya terurai (terlepas), dan kemudian membentuk tanah yang subur. Tanah juga disebut lithosfer (lith = batuan) karena dibentuk dari hasil pelapukan batuan. Berdasarkan data yang dikumpulkan, maka jenis tanah yang terdapat di Kota Gorontalo adalah Ordo Inceptisol. Tanah ini terbentuk pada daerah curah hujan sedang sampai tinggi dan bisa juga di jumpai pada sepanjang aliran sungai. Tanah golongan ini terbentang luas di seputar garis khatulistiwa yaitu dari "Tropical of Cancer" sampaitropical of capricorn atau $220 \neg 30$ ” lintang selatan. berikut ini gambar sebaran jenis tanah di Kota Gorontalo.

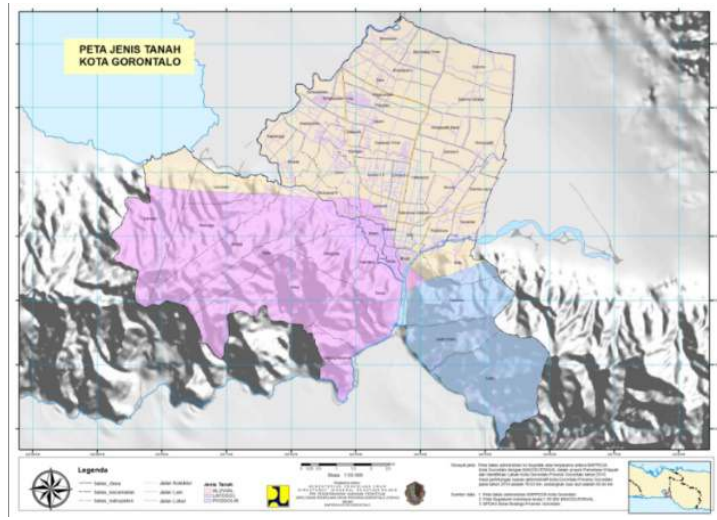

Gambar 1. Peta Jenis Tanah Kota Gorontalo

Tanah OrdoInceptisol mempunyai sifat fisik yang baik (struktur) tetapi berkemampuan rendah untuk menahan kations dan membutuhkan pemberian pupuk yang agak sering. Kedalaman efektif tanah ini mencapai $150 \mathrm{~cm}$. Kedalam efektif adalah suatu keadaan dimana akar bisa masuk sampai kedalaman tertentu untuk menyerap unsur hara sedangkan horison A (top soil) mempunyai kedalaman $0-35 \quad \mathrm{~cm}$. tabel berikut menggambarkan informasi keadaan jenis tanah di Kota Gorontalo berdasarkan luasan. Peran bahan organik terhadap sifat fisik tanah di antaranya merangsang granulasi, memperbaiki aerasi tanah, dan meningkatkan kemampuan menahan air. Peran bahan organik terhadap sifat biologis tanah adalah meningkatkan aktivitas mikroorganisme yang berperan pada fiksasi nitrogen dan transfer hara tertentu seperti N, P, dan S. Peran bahan organik terhadap sifat kimia tanah adalah meningkatkan kapasitas tukar kation sehingga memengaruhi serapan hara oleh tanaman. (Gaur, 1980).

\section{Struktur Perekonomian Masyarakat}

Struktur perekonomian Kota Gorontalo selama periode tahun 2008-2010 didominasi oleh sektor tersier sebesar 76-77 \% dengan kontribusi terbesar adalah sektor perdagangan, hotel dan restoran mencapai 19-21\%. Dimana pada sektor primer yakni pada bidang pertanian, pertambangan dan penggalian sedangkan sektor sekunder merupakan penyumbang terbesar kedua pada stuktur perekonomian Kota Gorontalo.

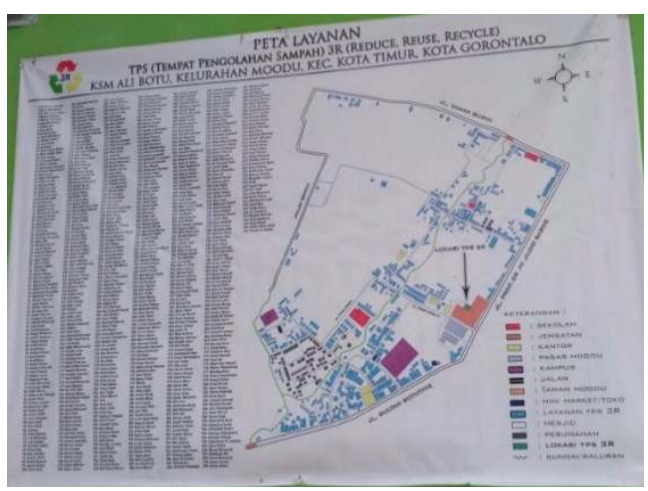

Gambar 2. Peta Layanan TPS KSM

Dari data TPS KSM di ketahui sampah rumah tangga di Gorontalo capai 200 ton per hari namun dari volume sampah Kota Gorontalo, jumlah armada tidak sesuai sehingga menyulitkan Dinas Lingkungan Hidup (DLH) Kota Gorontalo dalam pengangkutan sampah setiap hari."Tiap armada dapat mengangkut empat sampai lima ton per hari, sedangkan jumlah armada seKota Gorontalo hanya 22 unit.

Sementara itu, Bank Sampah Mutiara (BSM) di Kelurahan Moodu, Kecamatan Kota Timur, mampu menyerap sampah sebanyak $60 \mathrm{~kg}$ setiap hari di kelurahan Moodu Kota Gorontalo.Sampah yang terkumpul kemudian dipilah dan dikemas oleh empat pekerja KSM, dan dijual ke perusahaan swasta yang akan mengirimkannya ke Surabaya dan Malang kemudian sisanya untuk didaur ulang menjadi pupuk kompos namun dikarenakan pengolahan pupuk kompos yang manual sehingga para pekerja di TPS tidak membuatnya secara kontinyu. 

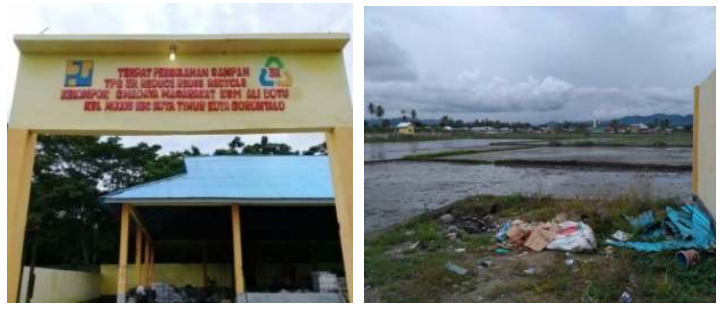

Gambar 3. Situasi lokasi pengolahan sampah di kelurahan Moodu, Gorontalo

\section{Deskripsi Alat TTG dan Produk yang dihasilkan}

Proses desain dilakukan dengan cara membuat desain pisau pecacah, sistem pengaduk dan proses penyaringan, Desain yang dipilih dari literature yang ada adalah desain dengan sistem paling sederhana yang mudah dibuat, murah dan praktis saatdioperasikan. Alternatif desain terpilih dibuat dari bahan alumunium sebagai tempat bioreactor pengomposan yangdilubangi dibawahnya dan ditambahkan lempengan alumunium sebagai alasnya yang berfungsi menampung komposjadi hasil saringan yang diletakan diantara dasar tong dengan tabung alumunium, sedangkan tong alumunium dibuat dengan diameter $40 \mathrm{~cm}$ dan tinggi $40 \mathrm{~cm}$ dengan dudukan ataupun penampung berupa laci sebagai wadah menampung hasil olahan pupuk kompos dengan tinggi keseluruhan mencapai $40 \mathrm{~cm}$. Pencacah dan pengaduk dibuat sekaligus dengan pisau berbentuk sabitdan digerakan otomatis melalui dynamo dengan system penghantar putaran yang sederhana.

Sampah organik yang telah dimasukan dan campuran sampah organik dengan starter teraduk secara horizontal danvertikal keatas kemudian jatuh kembali disebabkan oleh gaya gravitasi dan begitu pula seterusnya. Hasil kompos jadi ditampung dilaci alumunium, dibawah tabung alumunium dengan desain empat laci agar pengadukan atau pengomposan dapat dilakukan sebanyak 4 kali proses dengan cara mengganti laci yang terisi dengan laci kosong dibawahnya. Tutup didesain agar dapat dibuka tutup dengan tambahan corong samping sebagai hopper untuk memasukan sampah organic kedalam tong alumuniumPada proses prototyping sistem, desain sistem pengolahan atau pengaduk sampah menggunakan system mekanik sederhana dengan menggunakan dynamo sebagai penggerak utama.Alat diletakan di TPS Moodu ataudapat pula diletakan dipekarangan rumah untuk skala rumah tangga. Didalam produk telah terdapat Starter Composter yang merupakan kompos awal untuk mempercepat prosespengomposan. Desain pengomposan sampah organik didesain menggunakan bahan alumunium agar mendapat image higienis.

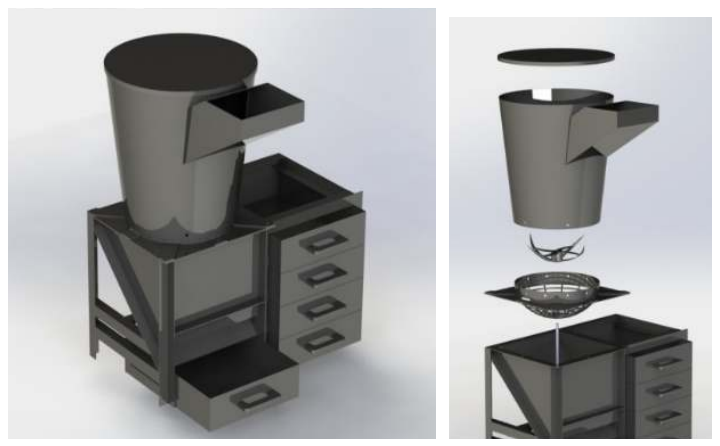

Gambar 4. Desain Alat Pengolah Sampah

Rumah Tangga Menjadi Pupuk Kompos

Cara Penggunaan alat pengomposan :

$\checkmark$ Masukan sampah organik kedalam tong alumunium melalui hopper samping

$\checkmark$ Nyalakan dynamo sebagai penggerak utama alat pengompos sampah

$\checkmark$ Ambil hasil kompos jadi didalam laci atas (bila ada).

$\checkmark$ Pindahkan laci yang sudah terisi pada pagian bawah dan tukar dengan laci kosong lainnya (begitu seterusnya)

$\checkmark$ Amati berapa hari pupuk kompos jadi setelah sampahorganik dimasukan.

$\checkmark$ Tabur kompos disawah depan TPS Moodu untuk meneliti keberhasilan produk dalam hal ini pupuk kompos dari sampah organik.

\section{Deskripsi Kompos}

Kompos adalah hasil penguraian parsial/tidak lengkap dari campuran bahanbahan organik yang dapat dipercepat secara artifisial oleh populasi berbagai macam mikroba dalam kondisi lingkungan yang hangat, lembap, dan aerobik atau anaerobik. (Crawford, 2003)

Sedangkan pengomposan adalah proses di mana bahan organik mengalami penguraian secara biologis, khususnya oleh mikroba-mikroba yang memanfaatkan bahan organik sebagai sumber energi. Membuat kompos adalah mengatur dan mengontrol 
proses alami tersebut agar kompos dapat terbentuk lebih cepat. Proses ini meliputi membuat campuran bahan yang seimbang, pemberian air yang cukup, pengaturan aerasi, dan penambahan aktivator pengomposan.

Sampah terdiri dari dua bagian, yaitu bagian organik dan anorganik. Rata-rata persentase bahan organik sampah mencapai $\pm 80 \%$, sehingga pengomposan merupakan alternatif penanganan yang sesuai. Kompos sangat berpotensi untuk dikembangkan mengingat semakin tingginya jumlah sampah organik yang dibuang ke tempat pembuangan akhir dan menyebabkan terjadinya polusi bau dan lepasnya gas metana ke udara. Secara alami bahan-bahan organik akan mengalami penguraian di alam dengan bantuan mikroba maupun biota tanah lainnya. Namun proses pengomposan yang terjadi secara alami berlangsung lama dan lambat. Untuk mempercepat proses pengomposan ini telah banyak dikembangkan teknologi-teknologi pengomposan. Baik pengomposan dengan teknologi sederhana, sedang, maupun teknologi tinggi.

\section{Proses Pengomposan}

Proses pengomposan akan segera berlangsung setelah bahan-bahan mentah dicampur. Proses pengomposan secara sederhana dapat dibagi menjadi dua tahap, yaitu tahap aktif dan tahap pematangan. Selama tahap-tahap awal proses, oksigen dan senyawa-senyawa yang mudah terdegradasi akan segera dimanfaatkan oleh mikroba mesofilik. Suhu tumpukan kompos akan meningkat dengan cepat. Demikian pula akan diikuti dengan peningkatan $\mathrm{pH}$ kompos. Suhu akan meningkat hingga di atas $50-70$ ${ }^{\circ} \mathrm{C}$. Suhu akan tetap tinggi selama waktu tertentu. Mikroba yang aktif pada kondisi ini adalah mikroba Termofilik, yaitu mikroba yang aktif pada suhu tinggi. Pada saat ini terjadi dekomposisi/penguraian bahan organik yang sangat aktif. Mikroba-mikroba di dalam kompos dengan menggunakan oksigen akan menguraikan bahan organik menjadi $\mathrm{CO}_{2}$, uap air dan panas. Setelah sebagian besar bahan telah terurai, maka suhu akan berangsurangsur mengalami penurunan. Pada saat ini terjadi pematangan kompos tingkat lanjut, yaitu pembentukan komplek liat humus. Selama proses pengomposan akan terjadi penyusutan volume maupun biomassa bahan.
Pengurangan ini dapat mencapai $30-40 \%$ dari volume/bobot awal bahan.

Proses pengomposan dapat terjadi secara aerobik (menggunakan oksigen) atau anaerobik (tidak ada oksigen). Proses anaerobik akan menghasilkan senyawasenyawa yang berbau tidak sedap, seperti: asam-asam organik (asam asetat, asam butirat, asam valerat, puttrecine), amonia, dan $\mathrm{H}_{2} \mathrm{~S}$.

Tabel 1. organisme yang terlibat dalam proses pengomposan

\begin{tabular}{|c|c|c|}
\hline $\begin{array}{l}\text { Kelompok } \\
\text { Organisme }\end{array}$ & Organisme & $\begin{array}{l}\text { Jumlah/gr } \\
\text { kompos }\end{array}$ \\
\hline Mikroflora & $\begin{array}{l}\text { Bakteri; } \\
\text { Aktinomicetes; } \\
\text { Kapang }\end{array}$ & $\begin{array}{l}10^{9}-10^{9} ; \\
10^{5} 10^{8} ; 10^{4} \\
-10^{6}\end{array}$ \\
\hline Mikrofanuna & Protozoa & $10^{4}-10^{5}$ \\
\hline Makroflora & $\begin{array}{l}\text { Jamur tingkat } \\
\text { tinggi }\end{array}$ & \\
\hline Makrofauna & $\begin{array}{ll}\text { Cacing } & \text { tanah, } \\
\text { rayap, } & \text { semut, } \\
\text { kutu, dll } & \end{array}$ & \\
\hline
\end{tabular}

Proses pengomposan tergantung pada :

1. Karakteristik bahan yang dikomposkan

2. Aktivator pengomposan yang dipergunakan

3. Metode pengomposan yang dilakukan

Kompos yang bermutu adalah kompos yang telah terdekomposisi dengan sempurna serta tidak menimbulkan efek-efek merugikan bagi pertumbuhan tanaman. Penggunaan kompos yang belum matang akan menyebabkan terjadinya persaingan bahan nutrien antara tanaman dengan mikroorganisme tanah yang mengakibatkan terhambatnya pertumbuhan tanaman. Kompos yang baik memiliki beberapa ciri sebagai berikut :

1. Berwarna coklat tua hingga hitam mirip dengan warna tanah,

2. Tidak larut dalam air, meski sebagian kompos dapat membentuk suspensi,

3. Nisbah $\mathrm{C} / \mathrm{N}$ sebesar $10-20$, tergantung dari bahan baku dan derajat humifikasinya,

4. Berefek baik jika diaplikasikan pada tanah,

5. Suhunya kurang lebih sama dengan suhu lingkungan, dan 


\section{Tidak berbau.}

\section{METODE PENELITIAN}

Beberapa aspek pokok pengamatan yang dilakukan adalah lokasi tempat pengolahan, kegiatan pemilahan jenis material, proses pengolahan dan mesin-mesin yang digunakan untuk pengolahan. Selain aspek pokok ini juga ada kegiatan lain yakni proses pengumpulan sampah dari rumah-rumah masyarakat khususnya yang berlokasi di kelurahan Moodu kecamatan Kota Timur Kota Gorontalo.

Mengenai lokasi pengolahan sampah, tempat ini memiliki dimensi luas bangunan $300 \mathrm{~m}^{2}$ yang di dalamnya terdapat bagianbagian petak yang digunakan untuk beberapa fungsi diantaranya adalah sebagai penampung, ruang mesin, ruang permentasi dan ruang pembakaran. Selain itu terdapat tempat untuk menampung material sampah dan tempat untuk hasil pemilahan sebelum dilakukan pengolahan. Berikut adalah kondisi tempat pengolahan sampah di kelurahan Moodu kecamatan Kota Timur :

Jenis material sampah yang dikumpul di tempat pengolahan ini adalah berupa plastik, kertas, kaleng, dan jenis sampah biomassa yang semuanya berasal dari sampah rumah tangga masyarakat di kelurahan Moodu. Pengamatan proses pengolahan sampah di lokasi ini, hanya kegiatan pemilahan jenis material dan pemusnahan sampah saja yang dilakukan. Untuk pengolahan biji plastik dan pengurai sampah organik sampai saat ini belum dilakukan. Sehingga dibutuhkan olat pengolah sampah organic rumah tangga.

\section{Tahap Pelaksanaan}

Pelaksanaan penelitian dilakukan dengan hapan sebagai berikut :

1. Menyediakan bahan yang akan digunaka antara lain sampah organik yang akan diolah, air, gula dan EM4

2. Sampah organik yang akan di olah ditimbang terlebih dahulu dengan menggunakan timbangan digital

3. Kemudian sampah organik yang telah dtitimbang dimasukkan kedalam mesin pencacah sampah
4. Nyalakan mesin pencacah sampah, hasil cacahan sampah akan keluar pada saringan bagian bawah tabung silinder mesin dan hasilnya akan tertampung pada laci yang sudah disediakan

5. Hasil cacahan sampah organik dicampurkan dengan air, gula dan EM4

6. Meletakan hasil campuran sampah organik dengan EM4 dilaci pada bagian alat yang telah disiapkan

7. Kegiatan percobaan dilakukan secara berulang sebanyak 4 kali sampai dengan semua laci pengomposan terisi

\section{HASIL DAN PEMBAHASAN}

\section{Desain Alat}

Perancangan alat dimulai dengan pembuatan rangka yang terbuat dari pipa kotak besi, tong alumunium dibuat dengan diameter $40 \mathrm{~cm}$ dan tinggi $40 \mathrm{~cm}$ dengan dudukan ataupun penampung berupa laci sebagai wadah menampung hasil olahan pupuk kompos dengan tinggi keseluruhan mencapai $40 \mathrm{~cm}$. Pencacah dan pengaduk dibuat sekaligus dengan pisau berbentuk sabit dan digerakan otomatis melalui dinamo dengan system penghantar putaran yang sederhana.
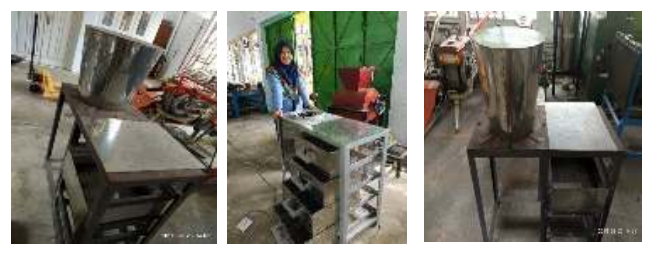

Gambar 5. Pembuatan alat pencacah dan pengompos sampah organik rumah tangga

\section{Hasil Pengujian Alat}

Hasil dari pengujian alat pengomposan telah dituangkan dalam tabel 2 dibawah ini :

Tabel 2. Hasil pengujian alat

\begin{tabular}{|c|l|l|c|l|}
\hline Pengujian ke- & $\begin{array}{c}\text { Berat } \\
\text { sampah } \\
\text { (gram) }\end{array}$ & \multicolumn{1}{|c|}{ Jenis sampah } & $\begin{array}{c}\text { Waktu } \\
\text { pencacahan } \\
\text { (detik) }\end{array}$ & $\begin{array}{c}\text { Kondisi Laci/rak } \\
\text { setelah } \\
\text { pengomposan }\end{array}$ \\
\hline I & 1200 & Sisa sayuran & 45 & Tidak berkarat \\
\hline II & 1200 & Sisa sayuran & 46 & Tidak berkarat \\
\hline III & 1200 & $\begin{array}{l}\text { Sisa sayuran + daun disertai } \\
\text { ranting-ranting kecil }\end{array}$ & 51 & Tidak berkarat \\
\hline IV & 1200 & $\begin{array}{l}\text { Sisa sayuran + daun disertai } \\
\text { ranting-ranting kecil }\end{array}$ & 50 & Tidak berkarat \\
\hline \multicolumn{4}{|c|}{ Rata-rata waktu pencacahan } & 48 detik \\
\hline
\end{tabular}


Dari tabel 2 dapat dilihat bahwa berat awal sampah yang diuji sama yakni 1200 gram dengan jenis sampah yang berbeda menunjukan juga waktu pencacahan yang berbeda. Pencacahan dengan jenis sampah sisa sayuran lebih cepat waktu pencacahannya dibandingkan dengan jenis sampah sisa sayuran yang ditambahkan dengan daun yang disertai ranting-ranting kecil. Rata-rata waktu pencacahan sampah organik dengan berat 1200 gram yakni 48 detik. Sehingga mesin ini mampu mencacah sampah organik dengan kapasitas 25 gr/detik. Setelah dilaksanakan pengomposan selama 7 hari, kondisi rak/laci pengomposan tidak berkarat.

\section{Pembuatan Pupuk Kompos}

Setelah menguji kinerja mesin pencacah sampah, dilanjutkan dengan pencampuran sampah organik dengan aktivator EM4.
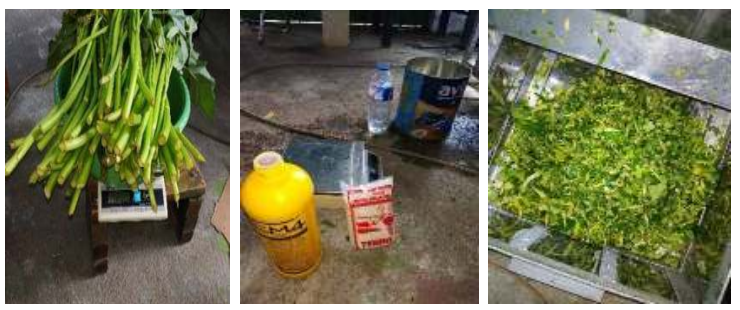

Gambar 6. Pembuatan pupuk kompos dari sampah organik

Setelah dilakukan pencampuran, sampah organik tersebut dimasukkan kedalam rak/laci untuk proses pengomposan. Sampah organik yang sudah tercampur dengan aktivator EM4 ditutup agar proses pengomposan berlangsung dengan sempurna.
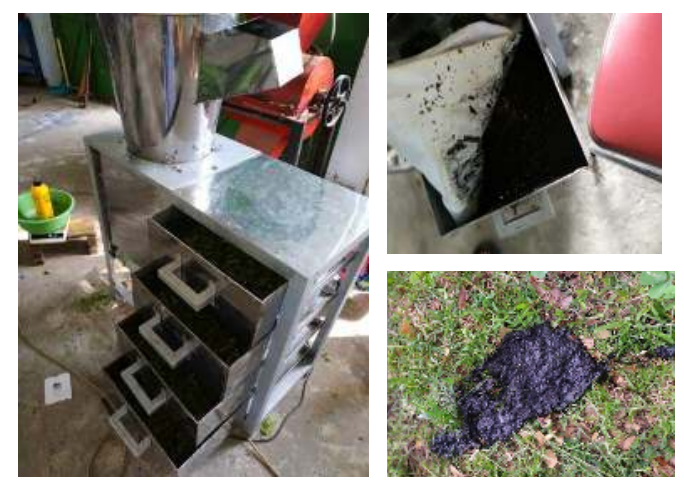

Gambar 7. Hasil pupuk kompos
Hasil dari pembuatan kompos dapat dilihat pada tabel 3 .

Tabel 3. Hasil akhir proses pengomposan

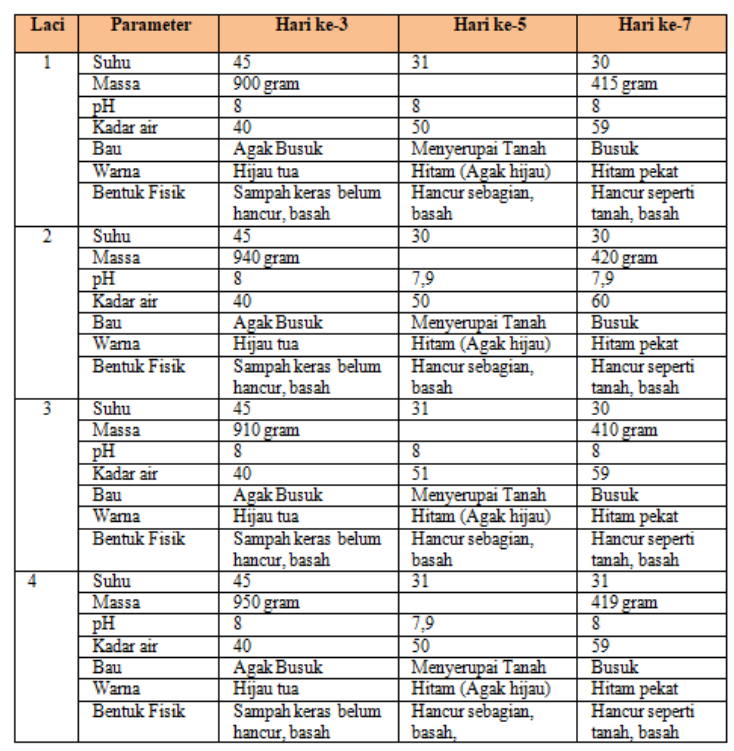

Berdasarkan tabel 3 diketahui bahwa semakin hari massa sampah yang akan dijadikan pupuk semakin menurun. Sama halnya juga dengan bentuk fisik dari sampah yang awalnya masih terpisah-pisah, pada hari ke tujuh sampah sudah menyatu. Bau dari sampah ini juga makin hari makin membusuk hal ini terjadi karena proses pengomposan tersebut. Dari tabel 3 juga dapat dilihat bahwa hasil pembuatan pupuk kompos dengan menggunakan aktivator EM4 sangat membantu mempercepat proses pengomposan. Pada hari ke 7 pupuk kompos dari sampah organik sudah jadi dan siap digunakan. Dari hasil tabel 3, maka dapat dilihat bahwa sampah yang dicacah menjadi bentuk yang lebih kecil-kecil dan dengan mencampurkan aktivator EM4 mampu mempercepat proses pengomposan.

\section{KESIMPULAN DAN SARAN}

\section{Kesimpulan}

1. Desain mesin pengomposan dirancang dengan menyesuaikan tinggi badan masayarakat pada umumnya dengan memperhatikan keamanan dan kenayaman pengguna. Bahan yang digunakan pada silinder pencacahan dengan laci penyimpanan kompos berupa stainless still 
agar tidak terjadai korosi atau berkarat akibat penggunaan bahan sampah yang basah. Penggerak mesin menggunakan dinamo untuk mempemudah pemakaian. Mesin pengomposan terdapat 4 buah rak/laci. Setiap rak/laci mempunyai volume $0,032 \mathrm{~m}^{3}$.

2. Rata-rata waktu pencacahan sampah organik dengan berat 1200 gram yakni 48 detik. Sehingga mesin ini mampu mencacah sampah organik dengan kapasitas $25 \mathrm{gr} /$ detik.

3. Dari hasil uji didaptkan bahwa sampah yang dicacah menjadi bentuk yang lebih kecil-kecil dan dengan mencampurkan aktivator EM4 mampu mempercepat proses pengomposan.

\section{Saran}

1. Hasil penelitian ini dilanjutkan dengan diseminasi/diperkenalkan kepada masyarakat.

2. Mata pisau pencacah dirancang yang lebih kuat dan tajam sehingga lebih mempercepat proses pencacahan.

\section{DAFTAR PUSTAKA}

Crawford, J. . (2003). KOMPOS. In Bogor: Balai Penelitian Bioteknologi Perkebunan Indonesia.

Gaur, A. L. (1980). A manual of rulal composting improving Soil Fertility through organic recycling. Project Field Document, No. 15.FAB. 